Political Control of the Economy 



\section{Political Control of the Economy}

Edward R. Tufte

Princeton University Press, Princeton, New Jersey 
Copyright (C) 1978 by Princeton University Press

Published by Princeton University Press, Princeton, New Jersey

In the United Kingdom: Princeton University Press, Chichester, West Sussex

All Rights Reserved

Library of Congress Cataloging in Publication Data will be

found on the last page of this book

This book has been composed in Linotype Times Roman

Princeton University Press books are printed on acid-free paper and meet the guidelines for permanence and durability of the

Committee on Production Guidelines for Book Longevity of the Council on Library Resources

Printed in the United States of America

Second printing, 1978

First Princeton Paperback, 1980

Seventh printing, 1994

ISBN 0-691-07594-8

ISBN 0-691-02180-5 (pbk.) 
TO MY PARENTS

Edward E. Tufte

and

Virginia James Tufte 
